\title{
Luteolin, an Abundant Dietary Component is a Potent Anti-leishmanial Agent that Acts by Inducing Topoisomerase II-mediated Kinetoplast DNA Cleavage Leading to Apoptosis
}

\author{
Bidyottam Mittra, ${ }^{1}$ Asim Saha, ${ }^{2}$ Arnab Roy Chowdhury, ${ }^{1}$ Chiranjib Pal, ${ }^{2}$ \\ Suparna Mandal, ${ }^{3}$ Sibabrata Mukhopadhyay, ${ }^{3}$ Santu Bandyopadhyay, ${ }^{2}$ \\ and Hemanta K. Majumder ${ }^{1}$ \\ ${ }^{1}$ Molecular Parasitology Laboratory, ${ }^{2}$ Cellular Immunology Division, ${ }^{3}$ Medicinal \\ Chemistry Division, Indian Institute of Chemical Biology, 4 Raja S.C. Mullick Road, \\ Calcutta, India
}

Accepted March 24, 2000.

\begin{abstract}
Background: Plant-derived flavonoids, which occur abundantly in our daily dietary intake, possess antitumor, antibacterial, and free radical scavenging properties. They form active constituents of a number of herbal and traditional medicines. Several flavonoids have been shown to exert their action by interacting with DNA topoisomerases and promoting site-specific DNA cleavage. Therefore, flavonoids are potential candidates in drug design. We report here that, although the flavonoids luteolin and quercetin are potent antileishmanial agents, luteolin has great promise for acting as a lead compound in the chemotherapy of leishmaniasis, a major concern in developing countries.

Materials and Methods: Kinetoplast DNA (kDNA) minicircle cleavage in drug-treated parasites was measured by electrophoresis of the total cellular DNA, followed by Southern hybridization using ${ }^{32} \mathrm{P}$ labeled kDNA as a probe. Cell cycle progression and apop-
\end{abstract}

tosis were measured by flow cytometry using propidium iodide and fluorescein isothiocyanate (FITC)labeled Annexin V.

Results: Luteolin and quercetin inhibited the growth of Leishmania donovani promastigotes and amastigotes in vitro, inhibited DNA synthesis in promastigotes, and promoted topoisomerase-IImediated linearization of kDNA minicircles. The IC $_{50}$ values of luteolin and quercetin were $12.5 \mu \mathrm{M}$ and $45.5 \mu \mathrm{M}$, respectively. These compounds arrest cell cycle progression in $L$. donovani promastigotes, leading to apoptosis. Luteolin has no effect on normal human T-cell blasts. Both luteolin and quercetin reduced splenic parasite burden in animal models. Conclusion: Luteolin and quercetin are effective antileishmanial agents. Quercetin has nonspecific effects on normal human $\mathrm{T}$ cells, but luteolin appears nontoxic. So, luteolin can be a strong candidate for antileishmanial drug design.

\section{Introduction}

The flavonoids are a large and complex group of compounds that occur throughout the plant kingdom, providing color and flavor. They exhibit a wide spectrum of pharmacological properties (1). Flavonoids form active con-

Address correspondence and reprint requests to: Dr. Hemanta K. Majumder, Molecular Parasitology Laboratory, Indian Institute of Chemical Biology, 4, Raja S. C. Mullick Road, Calcutta - 700 032, India. Fax: 91-33-473-5197/0284; E-mail: hkmajum@cal2. vsnl.net.in stituents of a number of herbal and traditional medicines (2). Quercetin and luteolin, important members of the flavonoid family, are present in fairly large amounts in fruits, vegetables, olive oil, red wine, tea, and the propolis of beehive (3). The average human daily intake of major flavonoids, such as quercetin, myricetin, luteolin, etc., is in the range of $16 \mathrm{mg}$ per day (4). In addition to having many therapeutic uses, quercetin was found to inhibit the growth of leukemic cells, Ehrlich ascites tumor cells, and other ascites tumor cells (5-8). Quercetin also was shown to 
potentiate the cytotoxicity of DNA-damaging anticancer drugs, such as cis-platin (9-11).

Several flavonoid compounds have been shown to exert their action by interacting with DNA topoisomerases, the key enzymes that govern important cellular processes like replication, transcription, recombination, integration, and chromosome segregation (12). The nonintercalating flavonoids, genistein and orobol, and the DNA-intercalating flavonoids, quercetin, myricetin, and biacelin, promote topoisomerasemediated, site-specific DNA cleavage in mammalian cells in vitro $(13,14)$.

Recently, it was reported that quercetin and the related flavones, acacetin, apigenin, kaempherol, and morin, inhibited eukaryotic topoisomerase I-catalyzed DNA religation. These compounds do not act directly on the catalytic intermediate and also do not interfere with DNA cleavage (15). As stabilization of topoisomerase II DNA "cleavable complex" is a known cytotoxic lesion in vivo, these flavonoids are potential candidates in designing antineoplastic, antibacterial, or antiparasitic drugs.

Leishmaniasis presents a spectrum of diseases ranging from benign cutaneous lesions, through the disfiguring mucocutaneous forms, to the often fatal visceralizing form (16). With the spread of human immunodeficiency virus (HIV) and general low standards of public hygiene, the parasites pose a much greater threat than before, particularly in developing countries. To make the situation even worse, some parasite strains also have developed resistance against the classical antimonial drugs, like sodium stibogluconate or megalumine antimonate. The second line of drugs, amphotericin B and pentamidines, although used clinically, are very toxic (17). Therefore, improved therapy of leishmanial infections is still desirable and the need for newer molecular targets on which to base the future treatment strategies clearly is justified.

In search for such strategies, the DNA topoisomerases of Leishmania offer most attractive targets. Leishmania parasites contain a unique DNA structure, the kinetoplast DNA (kDNA) within their mitochondria. kDNA is a network of thousands of topologically interlocked minicircles $(\sim 1 \mathrm{~kb})$ and several thousands of maxicircles $(\sim 25 \mathrm{~kb})$. Replication of this massive intercatenated network structure involves numerous topological interconversions. The re- lease and reattachment of individual minicircles from the network and the final splitting of the double-sized parent network into daughter networks all involve kinetoplast specific topoII-mediated manipulation of DNA topology (18). Several important anti-trypanosomal and anti-leishmanial drugs, like pentamidine, berenil or samorin, target the kinetoplast-specific topoisomerase II (19). These drugs and the antitumor drug, etoposide and 4-[9-Acridinylamino]$\mathrm{N}$-[methanesulfonyl]-m-anisidine (mAMSA) promote the formation of a "cleavable complex" between kinetoplast minicircle DNA and mitochondrial type II topoisomerase (20). Both type I and type II topoisomerases have been characterized in Leishmania $(21,22)$. A plant-derived bisnaphthoquinone, diospyrin, that induces topomediated DNA cleavage recently was reported from our laboratory (23). Identification of indigenous plant-derived compounds that induce topoisomerase-II-mediated cleavage of kDNA minicircles and have potentiality to act as lead compounds for drug design against leishmaniasis is our prime area of interest.

In the present study, we tested antileishmanial activity of five naturally occurring flavonoids: luteolin, quercetin, rutin, 5-hydroxy $3,6,7,3^{\prime}, 4^{\prime}$ pentamethoxy flavone (flavone A), and isoorientin (Fig. 1). Of these five flavonoids, luteolin and quercetin inhibit the growth of Leishmania donovani promastigotes, as well as amastigotes in infected macrophages in vitro, and induce cell cycle arrest at the Gl phase, leading to apoptosis. These two compounds also promote topoisomerase-II-mediated kDNA cleavage. The cleavable complex formation induced by these compounds can be correlated with their cytotoxicity towards the parasites in vitro. Also, oral administration of luteolin and quercetin, twice a week for one month, to golden hamsters 4 days post-infection, caused significant reduction of splenic parasite burden, compared with control untreated infected hamsters. Luteolin being more effective, our data suggest that this naturally occurring flavonoid can serve as a "lead" compound for much needed chemotherapy of leishmaniasis.

\section{Materials and Methods}

Isolation of Flavonoids

Luteolin $\left(5,7,3^{\prime}, 4^{\prime}\right.$-tetrahydroxy flavone), iso-orientin $\quad\left(5,7,3^{\prime}, 4^{\prime}\right.$-tetrahydroxy-6-C glucosyl flavone) and flavone A (5-hydroxy-3, 6,7,3', $4^{\prime}$ - 
<smiles>[R5]Oc1ccc(-c2oc3cc([R6])c([R2])c(O)c3c(=O)c2[R])cc1O[R2]</smiles>

\begin{tabular}{|c|c|c|c|c|c|c|}
\hline & & $\underline{R_{1}}$ & $\underline{R_{2}}$ & $\underline{R_{3}}$ & $\underline{R_{4}}$ & $\underline{R_{5}}$ \\
\hline Quercetin & $:$ & $\mathrm{OH}$ & $\mathrm{H}$ & $\mathrm{H}$ & $\mathrm{H}$ & $\mathrm{H}$ \\
\hline Rutin & $:$ & O-Glu-Rha & $\mathrm{H}$ & $\mathrm{H}$ & $\mathrm{H}$ & $\mathrm{H}$ \\
\hline Luteolin & & $\mathrm{H}$ & $H$ & $\mathrm{H}$ & $\mathrm{H}$ & $\mathrm{H}$ \\
\hline $\begin{array}{l}\text { Flavone } A \\
(5-\text { Hydroxy } \\
3,6,7,3^{\prime}, 4^{\prime} \\
\text { pentametho }\end{array}$ & & flavone) & $\mathrm{OCH}_{3}$ & $\mathrm{CH}_{3}$ & $\mathrm{CH}_{3}$ & $\mathrm{CH}_{3}$ \\
\hline Isoorientin & : & $\mathrm{H}$ & $C-G \mid u$ & $\mathrm{H}$ & $\mathrm{H}$ & $\mathrm{H}$ \\
\hline
\end{tabular}

Fig. 1. Structures of the flavonoids.

pentamethoxy flavone) were isolated from the leaves of Vitex negundo Linn. Quercetin $\left(3,5,7,3^{\prime}, 4^{\prime}\right.$-pentahydroxy flavone) and rutin $\left(5,7,3^{\prime}, 4^{\prime}\right.$-tetrahydroxy-3-O-rutinosyl flavone) were isolated from Fagopyrum esculentum (buckwheat). Isolation procedure followed the method described earlier $(24,25)$. The structures of the compounds were ascertained by spectroscopic analysis and by superimposable infrared (IR) spectra and undepressed mixed melting point with authentic samples.

\section{Enzymes, DNA and Chemicals}

Type II DNA topoisomerase and kDNA was purified from Leishmania strain UR6 promastigotes as described previously $(21,26) . \alpha^{32} \mathrm{P}$-dATP (3000 Ci/mmole) was purchased from Amersham Pharmacia Biotech U.K. Ltd. (Buckinghamshire) and ${ }^{3} \mathrm{H}$-thymidine $(6.70 \mathrm{Ci} / \mathrm{mmole})$ from New England Nuclear (Boston, MA). All other chemicals were of reagent grade or equivalent.

Drug Treatment of Intact Leishmania Parasites and Isolation of DNA

Exponentially growing $L$. donovani strain AG83 promastigotes (27) were harvested from the liquid culture media and suspended in fresh media to a cell density of $10^{8}$ cells $/ \mathrm{ml}$. Cells were then incubated at $22^{\circ} \mathrm{C}$ for $15 \mathrm{~min}$. Flavone solutions in dimethyl sulfoxide (DMSO) were added as $20 \mathrm{X}$ concentrate to achieve the desired concentrations. The parasites were further incubated at $22^{\circ} \mathrm{C}$ for $30 \mathrm{~min}$ with occasional agitation. After incubation, parasites were washed with phosphate-buffered saline (PBS) and resuspended in STE buffer (10 mM $\mathrm{NaCl}, 10 \mathrm{mM}$ Tris.HCl pH7.9 and 1 mM EDTA). The cells were lysed by adding an equal volume of lysis buffer [10 mM Tris. $\mathrm{HCl}$ pH7.9, $75 \mathrm{mM}$ EDTA and $1 \%$ sodium dodecyl sulfate (SDS)]. The lysates were incubated at $55^{\circ} \mathrm{C}$ for $2 \mathrm{hrs}$ with $2 \mathrm{mg} / \mathrm{ml}$ proteinase $\mathrm{K}$, following which $150 \mu \mathrm{g} / \mathrm{ml}$ RNase A and 250 units/ml RNase Tl were added and further incubated at $37^{\circ} \mathrm{C}$ for 30 min. Digests were extracted with phenol and dialyzed overnight at room temperature against the above buffer and DNA was precipitated with ethanol (28).

\section{Analysis of DNA Cleavage}

Purified DNA (100 ng) from drug-treated parasites was digested with 20 units of exonuclease III (Boehringer Mannheim, Germany) and 100 units of $\lambda$-exonuclease (New England Biolab) separately, according to the protocol supplied by 
the manufacturers. DNA samples were subjected to electrophoresis in $2 \%$ agarose gel as described (21), transferred to Hybond N nylon membrane (Amersham-Life Science), and hybridized with $250 \mathrm{ng}$ of ${ }^{32} \mathrm{P}$-labeled kDNA probe $\left(10^{8} \mathrm{cpm} / \mu \mathrm{g}\right)$ at $55^{\circ} \mathrm{C}$ for $18 \mathrm{hr}(28)$. Filters were washed at a final stringency of $0.1 \mathrm{X}$ standard saline citrate (SSC), $0.5 \%$ SDS at $65^{\circ} \mathrm{C}$ and autoradiographed at $70^{\circ} \mathrm{C}$. Densitometry of autoradiographs was done with a microdensitometer (LKB BROMMA 2022 Ultrascan, Sweden).

\section{Decatenation Assay}

The standard decatenation assay mixture $(25 \mu \mathrm{l})$ contained $25 \mathrm{mM}$ Tris. $\mathrm{HCl} \mathrm{pH} 7.9,10 \mathrm{mM}$ $\mathrm{MgCl}_{2}, 0.1 \mathrm{mM}$ EDTA, $1 \mathrm{mM}$ Dithiothreitol (DTT), $50 \mathrm{mM} \mathrm{NaCl}, 10 \%$ glycerol, $1 \mu \mathrm{g}$ of kDNA, and 1 unit of Leishmania topoisomerase II ( 1 unit of enzyme activity is defined as the amount of enzyme needed for $50 \%$ decatenation of $1 \mu \mathrm{g}$ of kDNA networks into minicircles). The reaction was carried out at $30^{\circ} \mathrm{C}$ for $30 \mathrm{~min}$. Decatenation was monitored in $1 \%$ agarose gel as described above (21).

\section{Cytotoxicity Assay on L. donovani Promastigotes}

Cytotoxicity of the drugs was estimated by microscopic counting of the viable parasites after treatment with the flavones. Exponentially growing promastigotes (about $10^{6}$ cells per well) were added to 96-well microtitre plate in $199 \mu \mathrm{l}$ containing the drug solutions or DMSO in the media ( $1 \mu \mathrm{l}$ per well). The effects of each drug concentration were tested in triplicate. The plates were incubated at $22^{\circ} \mathrm{C}$ for $24 \mathrm{hrs}$, following which, $10 \mu \mathrm{l} \mathrm{sam}$ ples were taken from each well and viable cell counts were obtained with a hemocytometer.

Determination of Anti-leishmanial Activity

of Flavonoids on Intracellular

L. donovani Amastigotes

Thioglycolate-elicited peritoneal exudate was used as the source of macrophages for better recovery and easier isolation. Approximately $2.5 \times 10^{6}$ macrophages were allowed to adhere to glass cover slips $(20 \mathrm{~mm} \times 25 \mathrm{~mm})$ in Rosewell Park Memorial Institute-1640 medium supplemented with $10 \%$ fetal bovine serum (FBS) and cultured for 5 days at $37^{\circ} \mathrm{C}$ before in vitro infection with $L$. donovani. Stationary phase $L$. donovani promastigotes $\left(5.6 \times 10^{6}\right)$ were added to each cover slip and incubated for $6 \mathrm{hr}$ at $37^{\circ} \mathrm{C}$ in $5 \% \mathrm{CO}_{2}$. Cover slips were washed ( 3 times) with FBS-containing media to remove uningested parasites, and incubated for 2 days in the presence or absence of graded concentrations of the flavonoids indicated. Cultures were then washed with PBS, fixed with prechilled methanol, stained with Giemsa, and examined microscopically under oil immersion. At least 400 macrophages were examined for each cover slip. Anti-leishmanial activity was determined by calculating the number of amastigotes per 100 macrophages.

\section{Analysis of Cell Cycle Progression and Apoptosis by Flow Cytometry}

In vitro grown $L$. donovani promastigotes and normal human T-cell blasts were analyzed for cell cycle progression. T-cell blasts were prepared by culturing peripheral blood mononuclear cells (PBMC), isolated from freshly drawn heparinized blood by Ficoll/Hypaque density gradient centrifugation in RPMI- 1640 medium containing $10 \%$ FBS and $5 \mu \mathrm{g} / \mathrm{ml}$ photohemagglutinin (PHA) for 3 days at $37^{\circ} \mathrm{C}$ in $5 \% \mathrm{CO}_{2}$. Cells were fixed with $40 \%$ ethanol, treated with $500 \mu \mathrm{g} / \mathrm{ml}$ RNase A, and then with $69 \mu \mathrm{M}$ propidium iodide (PI), for analysis of DNA content by flow cytometry.

L. donovani promastigotes also were labeled with fluorescein isothiocyanate (FITC)-conjugated Annexin V (Boehringer Mannheim) following manufacturer's instruction. Cells were counter stained with $5 \mu \mathrm{g} / \mathrm{ml}$ PI without any detergent or fixative. In these conditions, PI stains necrotic (or late apoptotic) cells only, while being excluded by intact (both normal and early apoptotic) cells. Bivariate measurements of green fluorescence (identifyingAnnexin-labeled cells) versus red fluorescence (identifying cells with damaged membranes) were made with a fluorescence-activated cell sorter (FACS Calibur, Becton Dickinson) flow cytometer and data were analyzed using the Cell Quest program, Becton Dickinson, USA.

\section{Determination of Anti-leishmanial Activity of the Compounds in vivo}

Male golden hamsters (6 weeks old, weighing 60-75 g) were divided into three groups with five animals per group. Luteolin and quercetin were administered orally as follows: one group of hamsters received luteolin $(3.5 \mathrm{mg} / \mathrm{kg}$ body 
weight) twice a week at 4 days post-infection with freshly purified amastigotes of L. donovani AG83 $\left(2 \times 10^{7} /\right.$ hamster $)$ and treatment was continued for 4 weeks. One group of hamsters received quercetin using the same protocol as that of luteolin, except that quercetin was used at a dose of $14 \mathrm{mg} / \mathrm{kg}$ body weight. Hamsters in the control group received PBS by oral feeding twice a week for 4 weeks. Hamsters in all groups were killed 1 week after receiving the last treatment. The splenic parasite load was determined from impression smears after Giemsa staining. At least 800 nucleated cells were examined for each set. Results are expressed as the number of amastigotes/100 nuclei and the total parasite load per organ, using the formula (29):

Organ weight in $\mathrm{mg} \times$ the number of amastigotes per cell nucleus $\times\left(2 \times 10^{5}\right)$.

\section{Statistical Analysis}

Statistical analyses were performed by Student's $t$-test with the program Tadpole III (written by T. H. Caradoc-Davies, Wakari Hospital, Dunedin, New Zealand, published and distributed by Biosoft, Cambridge, U.K.)

\section{Results}

Effect of Flavonoids on the Growth and DNA Synthesis of Leishmania Promastigote Cells

To determine the effect of flavonoids on the growth of Leishmania, AG83 promastigotes were exposed to different concentrations of the compounds as described in "Materials and Methods." Following incubation for $24 \mathrm{hrs}$ at $22^{\circ} \mathrm{C}$, the numbers of live promastigotes were estimated by direct microscopic counting. Figure 2A shows the percentage of live promastigote cells grown in the presence of varying drug concentrations, relative to the control cells. Excepting for rutin, all other flavonoids, quercetin, luteolin, flavone A, and isoorientin, showed significant does-dependent anti-leishmanial activity. Luteolin and quercetin were found to be better inhibitors of promastigote cell growth, with IC $_{50}$ values of $12.5 \mu \mathrm{M}$ and $45.5 \mu \mathrm{M}$, respectively. The flavonoids luteolin and quercetin induced drastic morphological changes of the parasites, as evidenced by loss of cellular integrity and degranulated nuclei of the promastigotes (Fig. 2B, C and D).
At IC $_{50}$ concentrations of the flavonoids, $\left[{ }^{3} \mathrm{H}\right]$ thymidine incorporation was reduced to about $60 \%$ of the control with luteolin and $50 \%$ of the control with quercetin within $2 \mathrm{hr}$ of addition of these flavonoids. A concentrationdependent inhibition of $\left[{ }^{3} \mathrm{H}\right]$ thymidine incorporation was observed for both the flavonoids. With the increased concentrations of quercetin and luteolin, the thymidine incorporation was lowered further, to about $25 \%$ and $10 \%$, respectively, of the control following $6 \mathrm{hr}$ of incubation. The DMSO control cells incorporated $\left[{ }^{3} \mathrm{H}\right]$ thymidine at a steady level (Fig. 2E).

\section{Luteolin and Quercetin were Effective at Destroying Intracellular Amastigotes of $\mathrm{L}$. donovani in vitro}

The protozoan parasite, $L$. donovani, survives and multiplies within mammalian macrophages. It is, therefore, of interest to test the efficacy of the flavonoids on intracellular amastigotes. Peritoneal macrophages of BALB/c mice were infected in vitro with $L$. donovani and then incubated with graded concentrations of luteolin and quercetin. As shown in Table 1, luteolin was more effective than quercetin at decreasing the number of intracellular amastigotes. Both luteolin and quercetin at final concentrations of $3.12 \mu \mathrm{M}$ and $10.5 \mu \mathrm{M}$, respectively, reduced intracellular parasite burden only marginally, compared with medium or DMSO controls. Significant anti-leishmanial activity of quercetin was detectable at a concentration as high as $45.5 \mu \mathrm{M}$ (reduction of intracellular amastigotes load by $70 \%$ ). However, luteolin at a final concentration as low as $12.5 \mu \mathrm{M}$ reduced the intracellular parasite load by $70 \%$. Micrographs of Giemsastained L. Donovani-infected BALB/c mice peritoneal macrophages incubated with luteolin and quercetin are shown in Fig. 3.

\section{Luteolin and Quercetin Promote Linearization of kDNA Minicircles}

To determine whether the inhibitory effect of the flavonoids on DNA synthesis and their subsequent cytotoxicity would be due to their ability to induce topoisomerase-II-mediated DNA cleavage, we examined the effect of flavonoid treatment on minicircle DNA. As described in the "Materials and Methods," $L$. donovani AG83 promastigotes were treated with $1 \%$ DMSO or with various flavonoids at $22^{\circ} \mathrm{C}$ for $60 \mathrm{~min}$ and then lysed with SDS. The purified DNA was then isolated, resolved by 
A

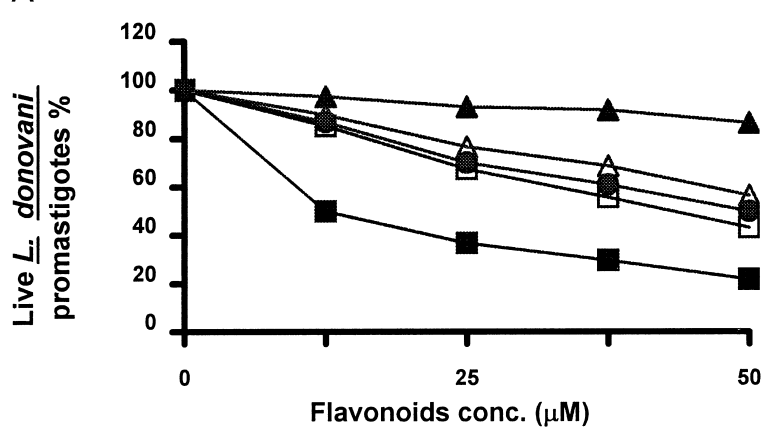

B

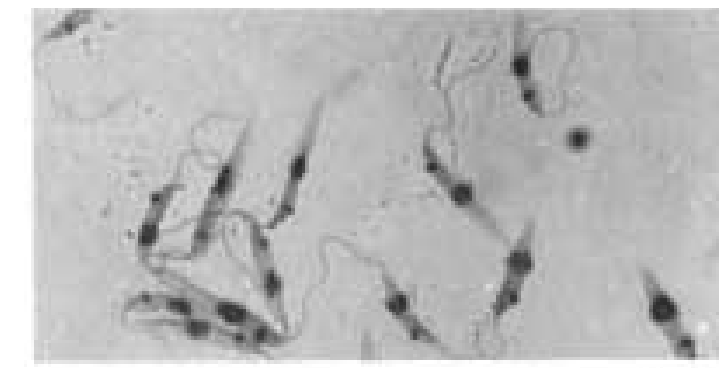

C

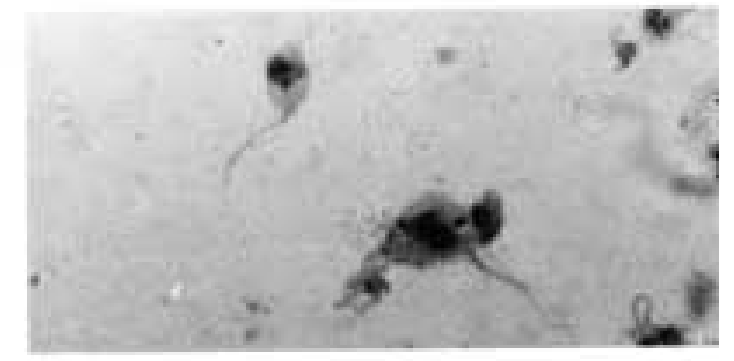

D

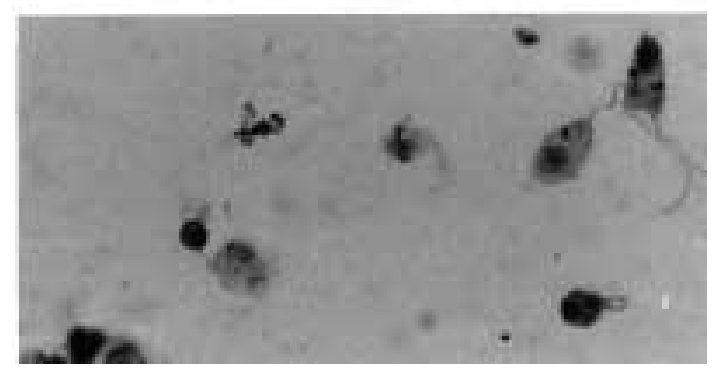

$\mathrm{E}$

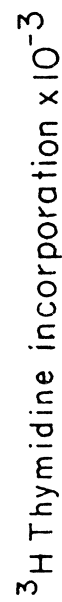

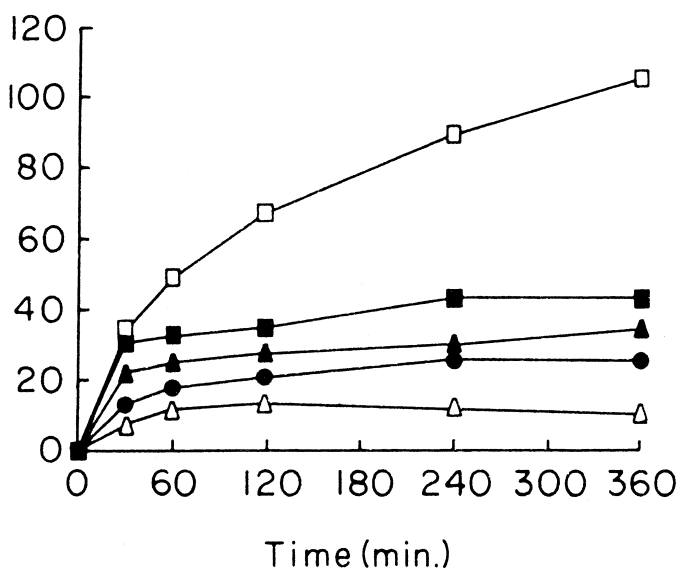

Table 1. In vitro anti-leishmanial activity of flavonoids on intracellular amastigotes of L. donovani ${ }^{a}$

\section{Treatment}

Amastigotes/100 Nuclei

Medium

$892.3 \pm 21.0^{\mathrm{b}}$

DMSO (0.2\%)

Luteolin $(3.12 \mu \mathrm{M})$

(12.5 $\mu \mathrm{M})$

Quercetin (11.5 $\mu \mathrm{M})$

(45.5 $\mu \mathrm{M})$

$1007.6 \pm 40.1$

$754.6 \pm 129.6$

$320.3 \pm 23.8$

$796.0 \pm 14.7$

$312.0 \pm 22.6$

${ }^{a}$ Thioglycolate-elicited peritoneal macrophages of BALB/ $C$ mice were infected in vitro with $L$. donovani amastigotes and incubated with graded concentrations of luteolin and quercetin (dissolved in DMSO) for 2 days at $37^{\circ} \mathrm{C}$ for the determination of anti-leishmanial activity on intracellular amastigotes as described in "Materials and Methods."

${ }^{b}$ Mean \pm SD of triplicate determinations.

agarose gel electrophoresis, transferred to Hybond $\mathrm{N}$ membrane and hybridized with ${ }^{32} \mathrm{P}-\mathrm{la}-$ beled kDNA. By this method, the free minicircles entered the gel; whereas, the minicircles catenated in the network remained in the slot. For the control cells, the free minicircle

Fig. 2. In vitro cytotoxicity of flavonoids and inhibition of DNA synthesis on cultured $L$. donovani AG83 promastigotes. (A) L. donovani promastigotes were cultured in M199 medium for $24 \mathrm{hr}$ at $22^{\circ} \mathrm{C}$ with increasing concentrations of quercetin (- $\square-)$, rutin (- $\mathbf{\Delta}-)$, luteolin (-口-), flavone A (- $\triangle-)$ and isoorientin (-O-). Cell numbers determined by microscopic counting are expressed as percentages of those determined for cells grown in presence of $0.5 \%$ DMSO used as drug vehicle. All measurements were made in triplicate. (B-D) Micrographs of Giemsa stained L. donovani AG83 promastigotes in culture media containing $0.5 \%$ DMSO (B), $50 \mu \mathrm{M}$ quercetin (C), or $20 \mu \mathrm{M}$ luteolin (D). Note the healthy promastigotes in cultures containing $0.5 \%$ DMSO, and the lysed or roundshaped cells with degranulated nuclei in cultures containing quercetin or luteolin. Magnification 1000X. (E) Incorporation of $\left[{ }^{3} \mathrm{H}\right]$ thymidine $(100$ $\mu \mathrm{Ci} / \mathrm{ml}$ ) into DNA of $L$. donovani AG83 promastigotes was monitored following addition of $\left[{ }^{3} \mathrm{H}\right]$ thymidine and $0.25 \%$ DMSO (- $\square-) ; 12.5 \mu \mathrm{M}$ luteolin (- $\Delta-) ; 50 \mu \mathrm{M}$ luteolin $(-\triangle-) ; 40 \mu \mathrm{M}$ quercetin (-口-) or $100 \mu \mathrm{M}$ quercetin (-๑-) to parasite cultures $\left(3 \times 10^{6}\right.$ cells $\left./ \mathrm{ml} ; 22^{\circ} \mathrm{C}\right)$ at time 0 . Aliquots of $100 \mu \mathrm{l}$ each were withdrawn from the cultures at indicated time intervals and processed to determine the incorporation of label into acid precipitable DNA. All measurements were done in triplicate. 

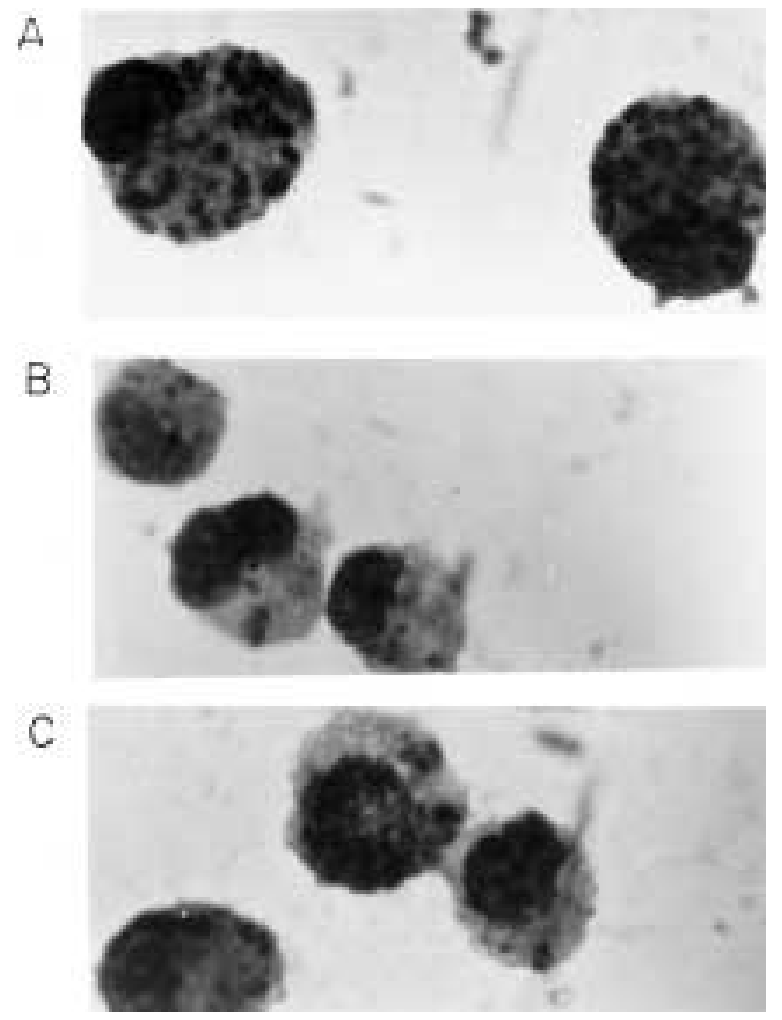

Fig. 3. Micrographs of Giemsa-stained L. donovani infected BALB/c peritoneal macrophages. Peritoneal macrophages were incubated for 2 days at $37^{\circ} \mathrm{C}, 5 \% \mathrm{CO}_{2}$, in medium containing $0.2 \%$ volume per volume (v/v) DMSO (A), $12.5 \mu$ M luteolin (B), or $45.5 \mu \mathrm{M}$ quercetin (C). Magnification 1000X. Note the presence of healthy intracellular amastigotes in cultures incubated with media (containing DMSO) and the degraded intracellular amastigotes in cultures incubated with luteolin or quercetin.

population consisted of monomeric forms that were usually covalently closed or nicked circles, and very few full-length linearized molecules (Fig. 4A, lane 1). However, following treatment with the flavonoids, there was an increase of the total mass of free minicircles and a dramatic enhancement of the population of linearized minicircles (lanes 4-8). Of these flavonoids, quercetin (lane 4) and luteolin (lane 5) induced maximum linearization of the kDNA minicircles, and their effect was comparable to the linearization induced by etoposide (lane 3). Flavone A and isoorientin (lanes 7and 8) induced linearization of minicircles, but with less potency. The flavonoid rutin (lane 6), however, showed negligible potential to promote minicircle linearization, compared with other flavonoids.

Luteolin and quercetin promoted kDNA minicircle linearization in a dose-dependent manner (Fig. 4B and C). At $150 \mu \mathrm{M}$ concentra- tion of quercetin (Fig. 4B, lane 6), linearized minicircles constituted $40 \%$ of the total minicircle population, as determined by densitometry; whereas, with $100 \mu \mathrm{M}$ etoposide, $20 \%$ of the free minicircle population was linear (lane 2). In contrast, the DMSO-treated control cells (lane 1) had barely visible linearized minicircles. This suggested that quercetin was even more potent than etoposide at promoting minicircle cleavage. By densitometric analysis, the percentage of linear minicircles (form III) were calculated from the total population (forms I + II + III) released in each lane. The release of linear minicircles followed dose response, as the percentage of release were 15, 20, 35, 40 and $40 \%$, respectively, against doses of 25,50 , 100,150 and $200 \mu \mathrm{M}$ quercetin (lanes 3-7). Maximum linearization of minicircles was achieved with $10 \mu \mathrm{M}$ luteolin (Fig. 4C, lane 3) and further increases in the concentration of the flavonoid did not enhance the linearization of the minicircles (lanes 4-6). The extent of minicircle linearization by luteolin at $10 \mu \mathrm{M}$ (lane 3) was comparable to that achieved with $10 \mu \mathrm{M}$ mAMSA (lane 7).

\section{Linearized Minicircles have Proteins Linked at Their 5' Termini}

To check whether any protein was linked covalently to the linearized minicircle DNA, the cell lysates of quercetin- and luteolin-treated parasites were extracted with phenol-chloroform, with and without prior proteinase $\mathrm{K}$ treatment. When the cell lysate was not digested with proteinase $K$, prior to the phenolchloroform extraction, the linearized minicircles selectively were lost from the aqueous phase (Fig. 4D, lane 2); whereas, linearized minicircles were present in proteinase $\mathrm{K}$ treated cell lysate (lane 1). This was consistent with the notion that these linear minicircle DNA molecules were linked covalently to protein and that they were generated from quercetin-stabilized kinetoplast topoII-minicircle DNA complexes in vivo. Treatment with luteolin also yielded similar results (data not shown). To determine whether the protein was linked to the $3^{\prime}$ - or $5^{\prime}$-ends of the linearized minicircles, the purified DNA isolated from the quercetin-treated cells was digested with either $\lambda$ exonuclease (a 5'-3' exonuclease), or exonuclease III (a $3^{\prime}-5^{\prime}$ exonuclease). The quercetin-induced linearized minicircles were found to be sensitive to exonuclease III (lane 3), 
A
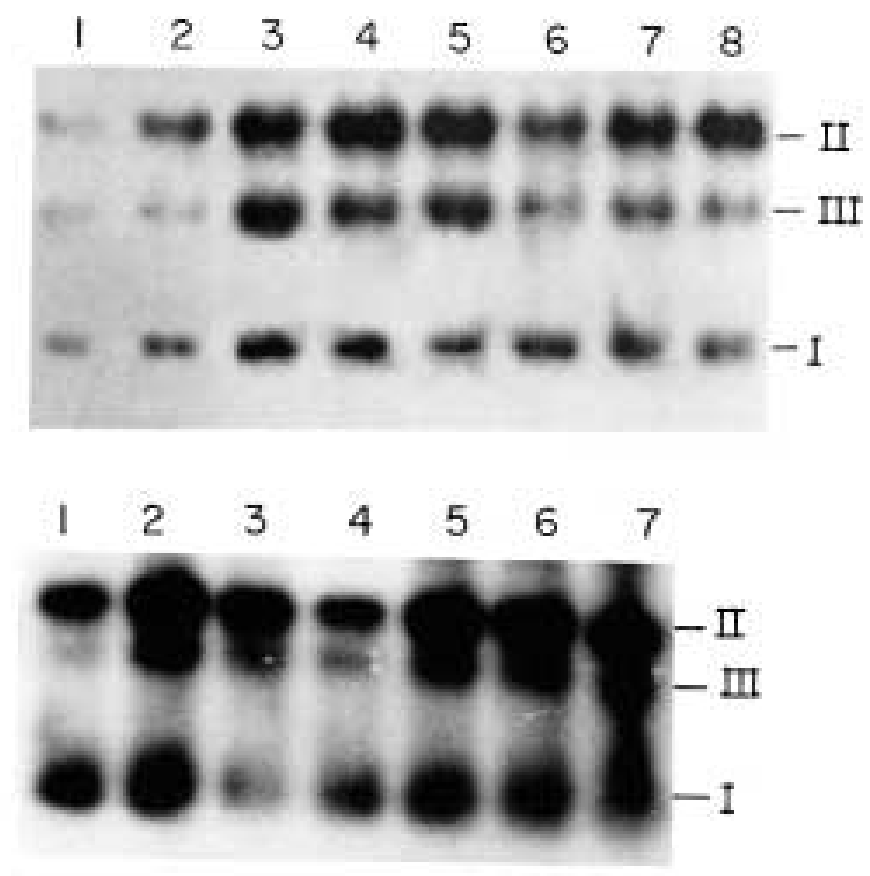

C
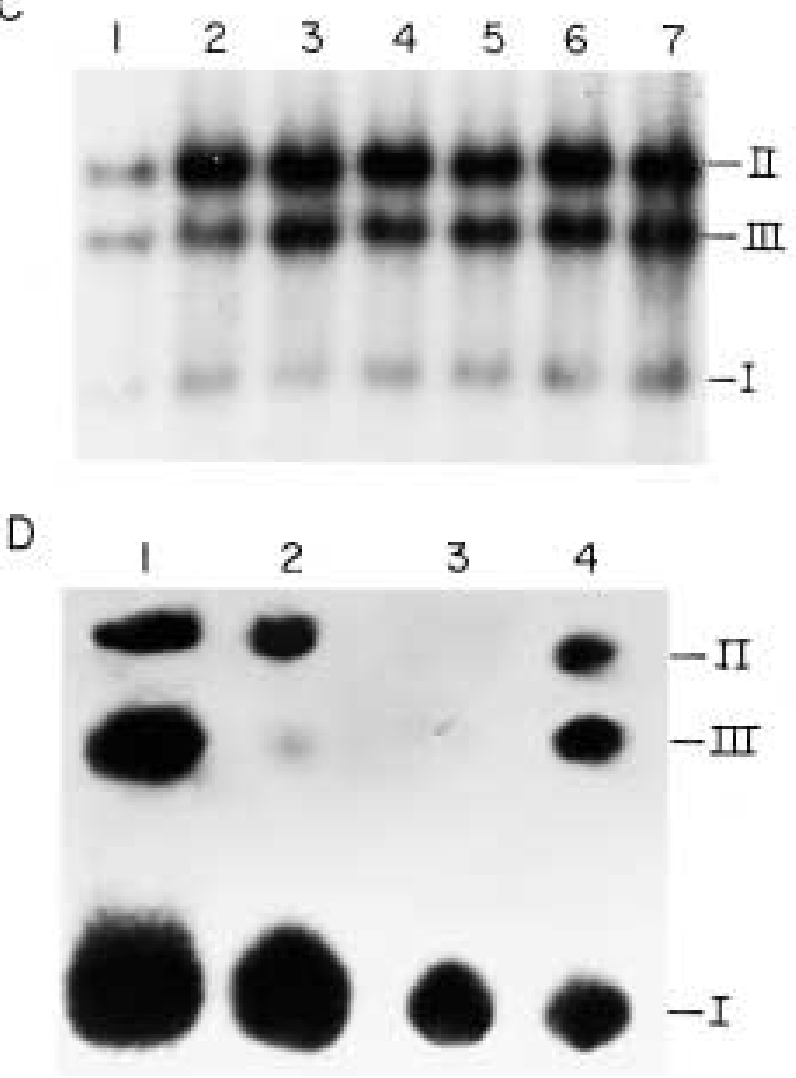

Fig. 4. Luteolin and quercetin induce cleavage of kDNA minicircles. (A) L. donovani AG83 promastigotes $\left(5 \times 10^{7}\right.$ cells $\left./ \mathrm{ml}\right)$ were treated with $0.5 \%$ DMSO or the flavonoids for $30 \mathrm{~min}$ and then lysed with SDS. SDS lysate was then digested with Proteinase K, RNase A and RNase Tl. After phenol extraction and ethanol precipitation, the DNA was resolved in a $2 \%$ agarose gel containing $0.5 \mu \mathrm{g} / \mathrm{ml} \mathrm{EtBr}$, transferred to Hybond $\mathrm{N}$ membrane and probed with ${ }^{32} \mathrm{P}$ labeled kDNA. Lane 1, DNA from control cells treated with IX PBS; lane 2, from control cells treated with $0.5 \%$ DMSO; lanes 3-8, from cells treated with etoposide $(100 \mu \mathrm{M})$, quercetin $(50 \mu \mathrm{M})$, luteolin $(20 \mu \mathrm{M})$, rutin $(100 \mu \mathrm{M})$, flavone A (100 $\mu \mathrm{M})$ and isoorientin $(100 \mu \mathrm{M})$, respectively. II, minicircles containing nicks or gaps; III, linearized minicircles; I, covalently closed minicircles. (B) L. donovani AG83 promastigotes $\left(5 \times 10^{7}\right.$ cells $\left./ \mathrm{ml}\right)$ were treated with increasing concentrations of quercetin. Linearization of kDNA minicircles were monitored as described in Panel A. Lane 1, DNA purified from control cells treated with $0.5 \%$ DMSO; lane 2, from cells treated with $100 \mu \mathrm{M}$ etoposide; lanes 3-7, from cells treated with increasing concentrations of quercetin at 25, 50, 100, 150 and $200 \mu \mathrm{M}$ respectively. (C) same as Panel B, excepting that the L. donovani promastigotes were treated with increasing concentrations of luteolin. Lane 1, DNA from cells treated with $0.5 \%$ DMSO; lanes $2-6$, from cells treated with $5,10,25,50$ and $100 \mu \mathrm{M}$ luteolin respectively; lane 7 , from cells treated with $10 \mu \mathrm{M}$ mAMSA. (D) Characterization of quercetin induced linearized minicircle DNA molecules. The DNA was processed in the same way as in Panel A, except proteinase $\mathrm{K}$ treatment was omitted as indicated. Lane 1, DNA purified from cells treated with $100 \mu \mathrm{M}$ quercetin; lane 2, DNA from cell lysate not digested with proteinase $\mathrm{K}$ prior to extractions with phenol and phenol-chloroform-isoamyl alcohol (25:24:1); lane 3, $100 \mathrm{ng}$ of purified DNA from quercetin-treated cells, digested with exonuclease III (10 units); lane 4, $100 \mathrm{ng}$ of purified DNA from quercetin-treated cells, digested with 10 units of $\lambda$ exonuclease. 


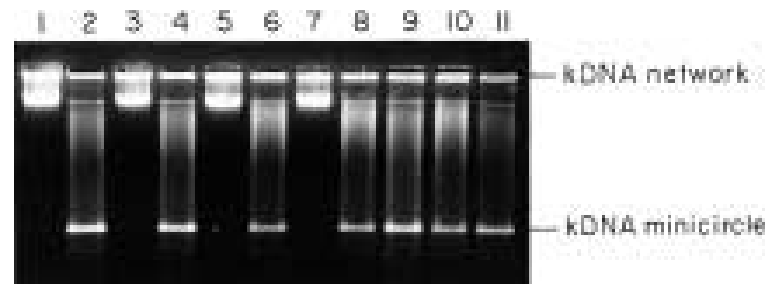

Fig. 5. Effect of flavonoids on strand passage activity of Leishmania topoisomerase II. One $\mu \mathrm{g}$ of kinetoplast DNA was treated with Leishmania topoisomerase II (1 unit) in the absence (lane 2) and presence of $50 \mu \mathrm{M}$ etoposide (lane 3 ) or flavonoids (lanes 4-10). Lanes 4 and 5, quercetin at 50 and $100 \mu \mathrm{M}$; lanes 6 and 7, luteolin at 12.5 and $50 \mu \mathrm{M}$; lane 8-10, flavoneA, rutin and isoorientin at $200 \mu \mathrm{M}$ concentrations, respectively. Lane 11 , $1 \mu \mathrm{g}$ of kDNA digested with 1 unit of PstI.

but were found to be resistant to $\lambda$ exonuclease treatment (lane 4). This experiment indicated that the protein trapped from the kinetoplast of the quercetin-treated Leishmania promastigotes was linked to both the 5 '-ends of the linearized double-stranded minicircle. The protein was presumably a type II topoisomerase and the subunits of the enzyme get linked to the 5 '-ends of the DNA following a topoII-mediated double-stranded minicircle DNA cleavage (30).

Flavonoids Inhibit the Catalytic Activity

of Topoisomerase II in vitro

The effect of the flavonoids on the DNA strand passage activity of topoisomerase II was determined with kDNA as substrate (Fig. 5). The topoisomerase II-released minicircles (lane 2) from the kDNA network (lane 1) in an ATPdependent reaction in vitro. Leishmania topoisomerase II was inhibited by both quercetin and luteolin. Luteolin was completely inhibitory in the decatenation assay at $50 \mu \mathrm{M}$ concentration (lane 7); whereas, quercetin inhibited the topoisomerase II activity at $100 \mu \mathrm{M}$ concentration (lane 5). Etoposide, a known topoisomerase II inhibitor, also inhibited the leishmanial enzyme at $33 \mu \mathrm{M}$ concentration (lane 3). The other flavonoids, isoorientin (lane 8), rutin (lane 9), and flavone A (lane 10) were much less inhibitory, even at $200 \mu \mathrm{M}$ concentrations.

Luteolin Arrested Cell-cycle Progression in L. donovani Promastigotes, Leading to Apoptosis, But Had No Effect on Normal Human T-cell Blasts

Cell-cycle analysis demonstrated that after 1 day of culture, luteolin and quercetin at $12.5 \mu \mathrm{M}$ and
$45.5 \mu \mathrm{M}$, respectively, caused $L$. donovani promastigotes to remain as resting G0/Gl cells and inhibited their entry into the $S$ phase. The percentage of dead cells did not increase during this incubation period, when growth arrest was visible. After 3 days of culture, both luteolin and quercetin caused substantial increases in cell death, compared with DMSOtreated cultures. As a positive control, L. donovani promastigotes were incubated at $37^{\circ} \mathrm{C}$, which reportedly induced apoptotic cell death in L. amazonensis promastigotes (31). Incubation of $L$. donovani promastigotes at $37^{\circ} \mathrm{C}$ resulted in the accumulation of the promastigotes at G0/Gl phase after 1 day and substantial accumulation of apoptotic cells after 3 days (Fig. 6 and Table 2 ). Of note, luteolin induced neither cell cycle arrest nor apoptosis on normal human T-cell blasts with up to 3 days of culture. However, arrest of T-cell blasts at the G0/Gl phase was detectable after incubation with quercetin for 3 days. Our results suggested that luteolin may be preferentially more active against $L$. donovani promastigotes at inducing cell-cycle arrest followed by apoptosis; whereas, the effect of quercetin appeared nonspecific as it induced cell-cycle arrest on normal human T-cell blasts as well.

That the flavonoids, luteolin and quercetin, induced apoptosis in $L$. donovani promastigotes was further confirmed by Annexin V labeling (Fig. 7). In early stages of apoptosis, dramatic changes in the organization of the plasma membrane took place among which was the translocation of phosphatidyl serine residues to the outer surface of apoptotic cells (32). Biparametric cytograms (Fig. 7) showed that neither media nor DMSO treatment induced apoptosis in $L$. donovani promastigotes $(<3.0 \%$ Annexin $\mathrm{V}$ positive cells in each case). In contrast, starting at 1 day of treatment with luteolin or quercetin, the percentage of apoptotic cells (Annexin V positive cells) progressively increased.

\section{Luteolin and Quercetin Reduced Splenic Parasite Burden in vivo}

The inhibition of promastigote growth, decatenating activity of topoisomerase II of Leishmania, induction of topoisomerase II-mediated kDNA minicircle cleavage, and apoptosis by luteolin and quercetin led us to further investigate the therapeutic potential of the flavonoids in animal models. L. donovani infection induced a progressive and fatal visceral leishmaniasis 
L. donovani promastigotes $1 d$
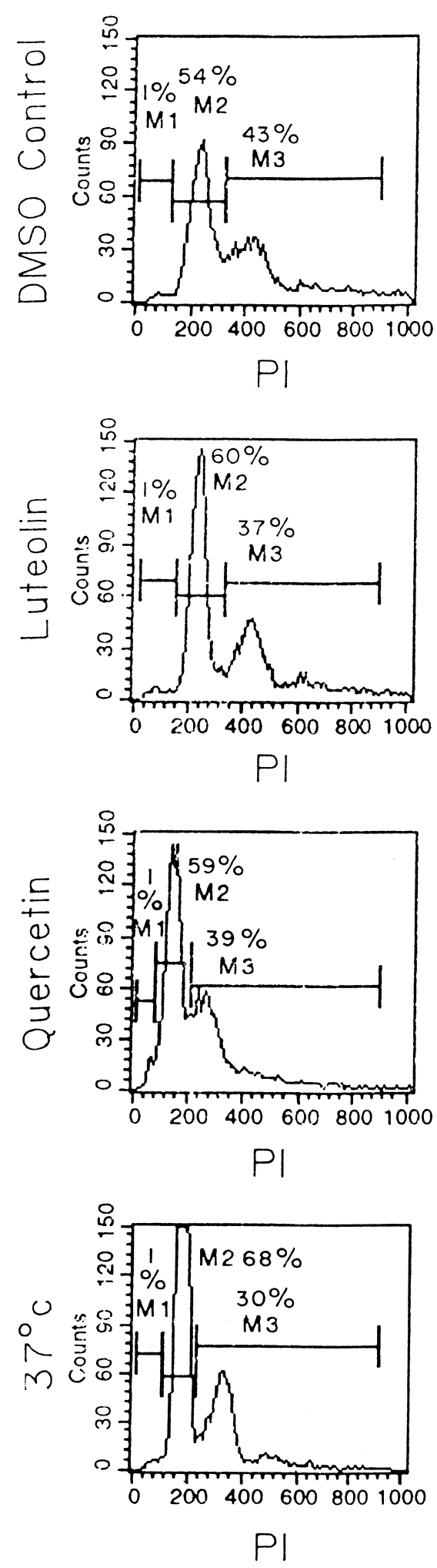
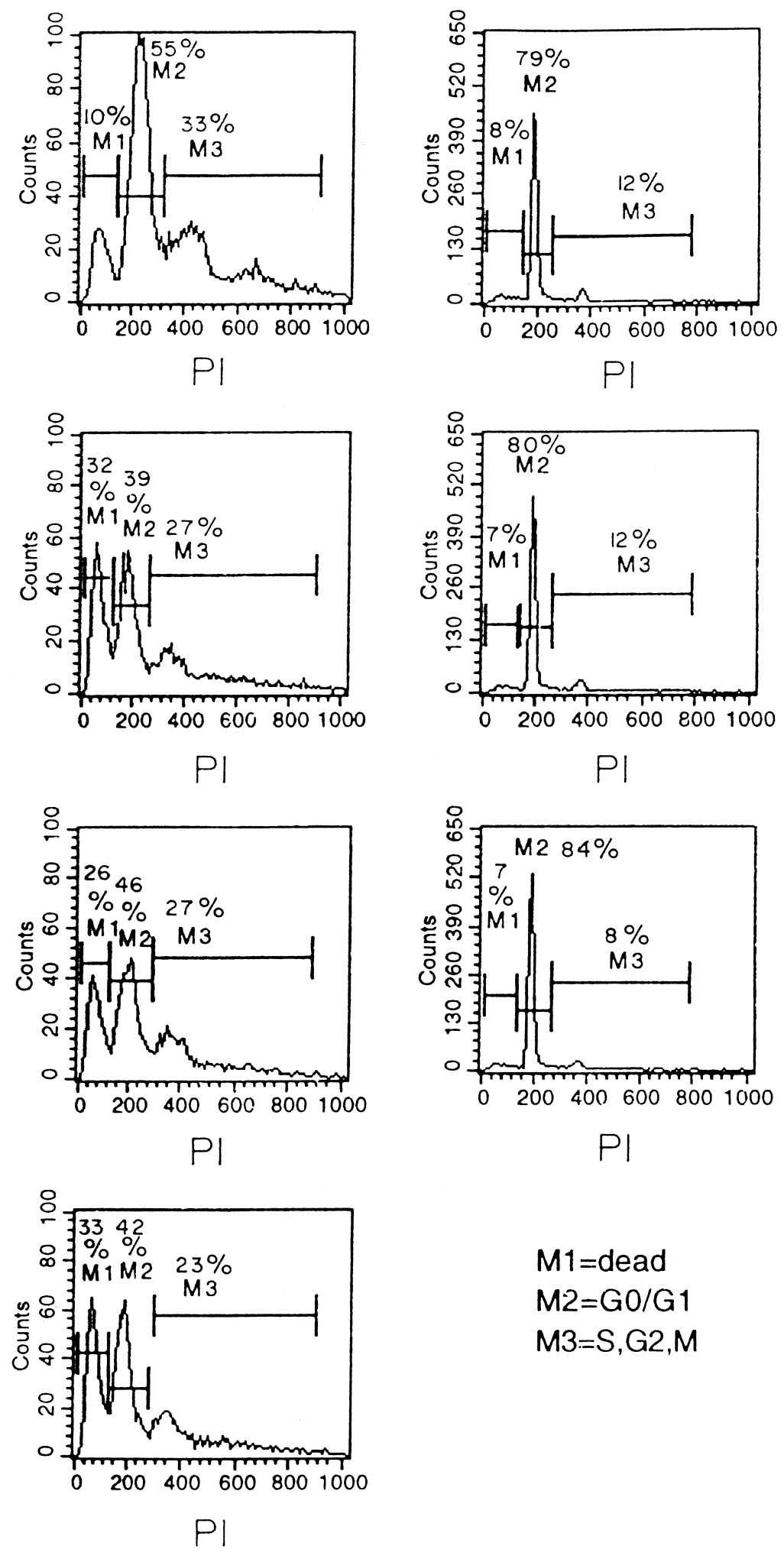

PBMC Blast $3 d$ 
Table 2. The percentage of cells in different phases of life cycle after treatment with luteolin or quercetin

\begin{tabular}{|c|c|c|c|c|c|}
\hline \multirow[b]{2}{*}{ Type of Cells } & \multirow[b]{2}{*}{ Incubated with } & \multicolumn{2}{|c|}{$M_{1}\left(\operatorname{sub} G_{0} / G_{1}\right.$ or dead $)$} & \multicolumn{2}{|c|}{$M_{2}\left(G_{0} / G_{1}\right)$} \\
\hline & & Id & $3 d$ & Id & $3 d$ \\
\hline \multirow{4}{*}{$\begin{array}{l}\text { L. donovani } \\
\text { promastigotes }\end{array}$} & DMSO alone & 1.0 & 10.0 & 54.0 & 55.0 \\
\hline & Luteolin & 1.0 & 32.0 & 60.0 & 39.0 \\
\hline & Quercetin & 1.0 & 26.0 & 59.0 & 46.0 \\
\hline & $\begin{array}{l}\text { DMSO alone } \\
\left(\text { at } 37^{\circ} \mathrm{C}\right)\end{array}$ & 1.0 & 33.0 & 68.0 & 42.0 \\
\hline \multirow[t]{3}{*}{ PBMC blast } & DMSO alone & & 8.0 & & 79.0 \\
\hline & Luteolin & & 7.0 & & 80.0 \\
\hline & Quercetin & & 7.0 & & 84.0 \\
\hline
\end{tabular}

PBMC, peripheral blood mononuclear cells; DMSO, dimethysulfoxide.

in golden hamsters. The degree of parasitemia in the spleen was monitored after treatment with the flavonoids. Like in vitro studies, luteolin was more effective at reducing splenic parasite burden of $L$. donovani-infected hamsters. Luteolin at a dose of $3.5-\mathrm{mg} / \mathrm{kg}$ body weight reduced the splenic parasite load by over $80 \%$. On the other hand, quercetin reduced the splenic parasite load by $90 \%$ (Table 3 ) at a concentration 4 times higher than that of luteolin (14 mg/kg body weight). Figure 8 shows the micrograph of Giemsa-stained splenic smears of infected golden hamsters (Fig. 8A) and subsequent reduction in the parasite burden when the animals were treated with quercetin (Fig. 8B) and luteolin (Fig. 8C).

\section{Discussion}

Flavonoids have attracted recent attention as novel inhibitors of DNA topoisomerases (13-15). Here, we demonstrate that quercetin and the related flavone, luteolin, inhibit the growth of Leishmania promastigotes and intracellular amastigotes in vitro and in vivo. However, luteolin appears to be significantly more effective than quercetin, as the $\mathrm{IC}_{50}$ value of luteolin is 3.5 times less than that of quercetin. The $\mathrm{IC}_{50}$ of luteolin is $12.5 \mu \mathrm{M}$, which corresponds to $3.4 \mu \mathrm{g} / \mathrm{ml}$ a dose, comparable to that of another known anti-leishmanial drug pentamidine (33). As both quercetin and luteolin are reported to promote mammalian topoisomerase II-mediated DNA cleavage (15), we investigated the ability of these flavonoids to induce topoisomerase II-mediated kDNA minicircle cleavage in Leishmania. Both luteolin and quercetin induce significant minicircle cleavage, luteolin having potency comparable to that of mAMSA. These data clearly indicate that the flavonoids can target the topoisomerase II enzyme in the kinetoplast of the parasites. When promastigote cells are exposed to quercetin or luteolin in the culture media, a significant enhancement of nicked form is observed along with the linearized minicircles, which are produced by topoisomerase II-medi-
Fig. 6. Luteolin and quercetin induce cellcycle arrest followed by death in $L$. donovani promastigotes. L. donovani promastigotes $(5 \times$ $\left.10^{6} / \mathrm{ml}\right)$ were incubated with DMSO $(0.2 \%)$, $12.5 \mu \mathrm{M}$ luteolin or $45.5 \mu \mathrm{M}$ quercetin (dissolved in DMSO) at $22^{\circ} \mathrm{C}$, and analyzed for DNA content by flow cytometry as described in "Materials and Methods." DNA content of T-cell blasts was analyzed in the same way, except that PHA $(5.0 \mu \mathrm{g} / \mathrm{ml})$ was induced in normal human peripheral blood mononuclear cells culture and incubation was carried out at $37^{\circ} \mathrm{C}$. Gates were set to assess the percentages of dead ( $<2 \mathrm{n}$ DNA), $\mathrm{G}_{0} / \mathrm{G}_{1}$ (2n DNA), and $S+G_{2}+n(>2 n$ DNA) cells. PI, propidium iodide; $\mathrm{PBMC}$, peripheral blood mononuclear cells; DMSO, dimethylsulfoxide. 
L. donovani promastigotes

$1 d$

$2 d$
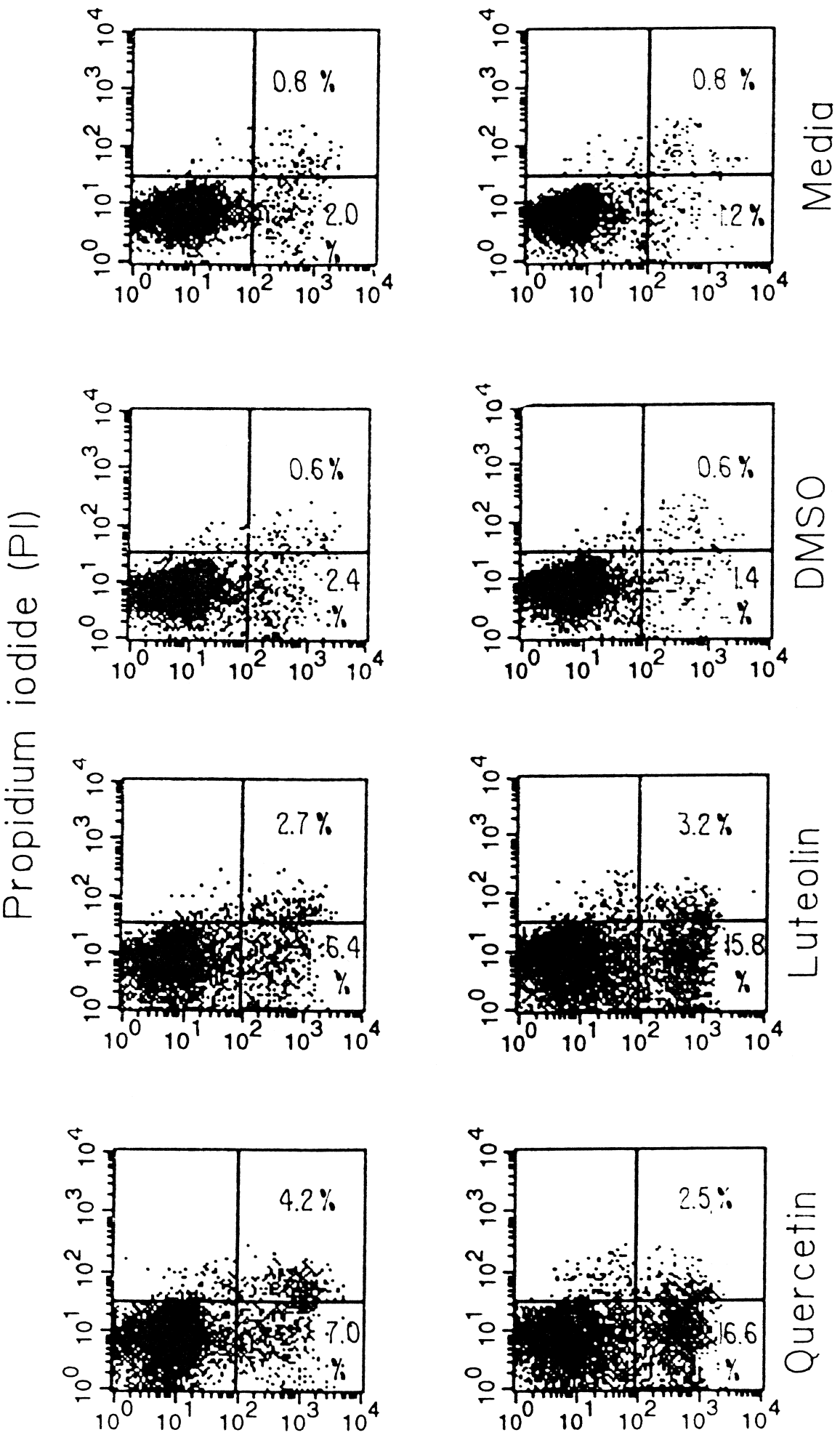

FITC-Annexin $V$ 
Table 3. In vivo anti-leishmanial activity of luteolin and quercetin

\begin{tabular}{lccc}
\hline Treatment with & $\begin{array}{c}\text { Dose (mg/kg } \\
\text { Body Weight) }\end{array}$ & $\begin{array}{c}\text { Amastigotes/100 } \\
\text { Spleen Cell Nuclei }\end{array}$ & $\begin{array}{c}\text { Total Parasite Load } \\
\left(\times 10^{8}\right)\end{array}$ \\
\hline PBS & - & $120.8 \pm 65.6$ & $1.1 \pm 0.7$ \\
Luteolin & 3.5 & $21.9 \pm 16.9^{a}$ & $0.19 \pm 0.12^{b}$ \\
Quercetin & 14.0 & $11.68 \pm 13.0^{a}$ & $0.09 \pm 0.13^{a}$ \\
\hline${ }^{a} p<0.04$ versus PBS; & & & \\
${ }^{b} p<0.05$ versus PBS & & & \\
\hline
\end{tabular}

ated double-strand cleavage of minicircles from the kDNA network. The enhancement of nicked circular DNA molecules (form II) with increased drug concentrations may be due to topoisomerase I-dependent minicircle DNA cleavage. Otherwise, these nicked minicircles may be released from the networks when neighboring circles are linearized, or they may be replicating intermediates, which are accumulated when the topoisomerase II activity is inhibited by the flavonoids. In vitro decatenation assays also show that both luteolin and quercetin inhibit the catalytic activity of type II DNA topoisomerase of Leishmania. Considering all these observations, it can be surmised that the flavonoids exert their anti-leishmanial effects primarily through topoisomerase inhibition, like the known anti-leishmanial drug, pentamidine, and the known anticancer drugs, etoposide and MAMSA.

Topoisomerase inhibition also leads to apoptosis of cells (34). We show here that these two topoisomerase II inhibitors induce cell cycle arrest, leading to apoptosis of $L$. donovani promastigotes. The above data led us to investigate the therapeutic potential of these two flavonoids in an animal model. Luteolin reduces splenic parasitic load to the same extent as quercetin, but at significantly lower concentration. The fact that the average daily intake of flavonoids in the diet is significantly high suggests that these compounds should be present in our system, even if the compounds are poorly absorbed from the digestive tract.

Luteolin appears nontoxic. Therefore, this flavonoid can also be used in combination therapy, along with classical anti-leishmanial drugs for better efficacy. Our in vitro and in vivo findings with this flavonoid make it a strong candidate for antileishmanial drug design.

\section{Acknowledgments}

The authors wish to thank Prof. A. N. Bhaduri, Ex-Director of this Institute for constructive criticism and interest in this work. The work was supported by a grant from Department of Biotechnology, Government of India (BT/ PRO493/MED/09/096/96) to HKM.
Fig. 7. Dual-parameter flow cytograms of FITC-labeled Annexin-V versus PI staining in L. donovani promastigotes. Cells were incubated with media, DMSO $(0.2 \%), 12.5 \mu \mathrm{M}$ luteolin and $45.5 \mu \mathrm{M}$ quercetin at $22^{\circ} \mathrm{C}$. Normal non-apoptotic cells were negative for both fluorescein isothiocyanate (FITC) and propidium iodide (PI) (lower left panels); relatively early apoptotic cells were labeled by Annexin- $V$ and were negative for PI (lower right panels); late apoptotic, as well as secondary necrotic, cells were labeled both for Annexin-V and PI (upper right panels). DMSO dimethysulfoxide. 

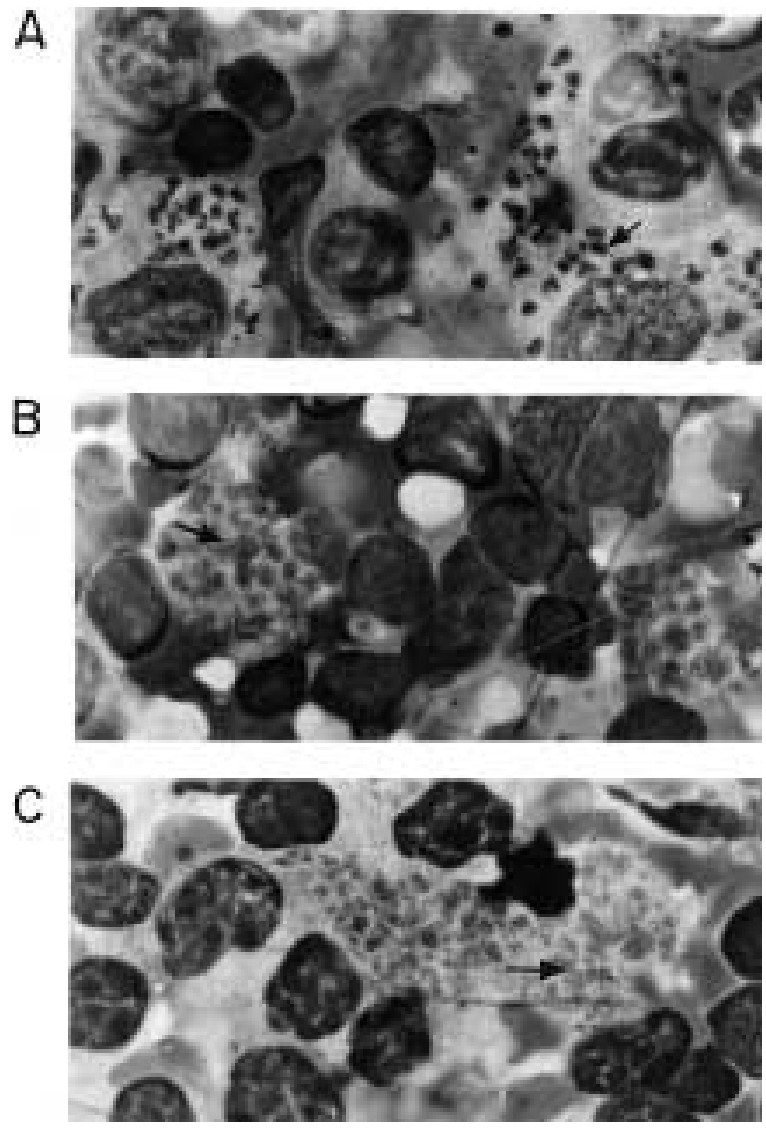

Fig. 8. Micrographs of Giemsa-stained splenic smears of L. donovani-infected golden hamsters after treatment with flavonoids. $L$. donovaniinfected golden hamsters were orally administered with phosphate buffered saline (A); quercetin, 14 $\mathrm{mg} / \mathrm{kg}$ body weight (B); and luteolin, $3.5 \mathrm{mg} / \mathrm{kg}$ body weight $(\mathrm{C})$. Note the presence of healthy amastigotes in spleens of hamsters receiving phosphate buffered saline (A), and the patches of degraded amastigotes (arrows) in animals treated with quercetin (B) and luteolin (C). Magnification 1000X.

\section{References}

1. Havsteen B. (1983) Flavonoids, a class of natural products of high pharmacological potency. Biochem. Pharmacol. 32: 1141-1148.

2. Wollenweber E. (1988). Occurrence of flavonoid aglycones in medicinal plants. Prog. Clin. Biol. Res. 280: 44-55.

3. Herrmann K. (1976) Flavonols and flavonones in food plants. J. Food Technol. 11: 433-448.

4. Hertog MGL, Hollman PCH, Katan MB, Krombout D. (1993) Intake of potentially anticarcinogenic flavonoids and their determinants in adults in Netharlands. Nutr. Cancer 20: 21-29.

5. Suolinna EM, Buchsbaun RN, Racker E. (1975) The effect of flavonoids on aerobic glycolysis and growth of tumor cells. Cancer Res. 35: 1865-1872.

6. Castillo MH, Perkins E, Campbell JH, et al. (1989) The effects of the bioflavonoid quercetin on squamous cell carcinoma of head and neck origin. American J. Surg. 188: 351-355.

7. Bibby MC, Double JA. (1993) Flavone acetic acid-from laboratory to clinic and back. Anticancer Drugs 4: 3-17.

8. Yoshida M, Yamato M, Nakaido T. (1992) Quercetin arrests human leukemic T-cells in late G1 phase of the cell cycle. Cancer Res. 55: 6676-6681.

9. Scambia G, Ranelletti FO, Benedetti PP, et al. (1990) Synergistic antiproliferative activity of quercetin and cisplatin on ovarian cancer cell growth. Anticancer Drugs 1: 45-48.

10. Teofili L, Pierelli L, Iovino MS, et al. (1992) The combination of quercetin and cytosine arabinoside synergistically inhibits leukemic cell growth. Leuk. Res. 16: 497-503.

11. Hofmann J, Fielig HH, Winterhalter BR, Berger DR, Grunicke H. (1990) Enhancement of the antiproliferative activity of cis-diamminedichloroplatinum(II) by quercetin. Int. J. Cancer 45: 536-539.

12. Wang JC. (1996) DNA topoisomerases. Annu. Rev. Biochem. 65: 635-692.

13. Yamashita Y, Kowada SZ, Nakano H. (1990) Induction of mammalian topoisomerase II dependent DNA cleavage by non-intercalative flavonoids, genistein and orobol. Biochem. Pharmacol. 39: 737-744.

14. Austin CA, Patel S, Ono K, Nakane H, Fisher LM. (1992) Site-specific DNA cleavage by mammalian DNA topoisomerase II induced by novel flavone and catechin derivatives. Biochem. J. 282: 883-889.

15. Boege F, Straub T, Kehr A, et al. (1996) Selected novel flavones inhibit the DNA binding or the DNA religation step of eukaryotic topoisomerase I. J. Biol. Chem. 271: 2262-2270.

16. Walton BC, Peters W, Killick-Kendrick R. (1987) American cutaneous and mucocutaneous leishmaniasis. In: Peters W, Killick-Kendrick R (eds.) The Leishmaniasis in Biology and Medicine. Academic Press, London, pp. 636-664.

17. Iwu MM, Jackson JE, Schuster BG. (1994) Medicinal plants in the fight against leishmaniasis. Parasitol. Today 10: 65-68.

18. Shapiro TA, Englund PT. (1995) The structure and replication of kinetoplast DNA. Annu. Rev. Microbiol. 49: 117-143.

19. Shapiro TA, Englund PT. (1990) Selective cleavage of kinetoplast DNA minicircles promoted by antitrypanosomal drugs. Proc. Natl. Acad. Sci. U.S.A. 87: 950-954.

20. Shapiro TA, Klein VA, Englund PT. (1989) Drug-promoted cleavage of kinetoplast DNA minicircles, the evidence for type II topoiso- 
merase activity in trypanosome mitochondria. J. Biol. Chem. 264: 4173-4178.

21. Chakraborty AK, Majumder HK. (1991) An ATP independent catenating enzyme from the kineplast hemoflagellate Leishmania donovani. Biochem. Biophys. Res. Commun. 180: 279-285.

22. Chakraborty AK, Gupta A, Majumder HK. (1993) A type I DNA topoisomerase from the kinetoplast hemoflagellate Leishmania donovani. Ind. J. Biochem. Biophys. 30: 257-263.

23. Ray S, Hazra B, Mittra B, Das A, Majumder HK. (1998) Diospyrin, a bisnaphthoquinone : novel inhibitor of type I DNA topoisomerase of Leishmania donovani. Mol. Pharmacol. 54: 994-999.

24. Dutta PK, Chaudhury US, Chakravarty AK, Achari B, Pakrashi SC. (1983) Nishindaside, a novel iridoid glycoside from Vitex negundo. Tetrahedron 39: 3067-3072.

25. Achari B, Chaudhury US, Dutta PK (1984) Two isomeric flavonones from Vitex negundo. Phytochemistry 23: 703-704.

26. Dasgupta S, Adhya S, Majumder HK. (1986) A simple procedure for the preparation of pure kinetoplast DNA network free of nuclear DNA from the kinetoplast hemoflagellate Leishmania donovani. Anal. Biochem. 158: 189-194.

27. Ghosh AK, Bhattacharya FK, Ghosh DK. (1985) Leishmania donovani: Amastigote inhibition and mode of action of berberine. Exp. Parasitol. 60: 404-413.

28. Sambrook J, Fritsch EF, Maniatis T. (1989) Molecular Cloning. A laboratory Manual, $2^{\text {nd }}$ ed., Cold
Spring Harbor Laboratory, Cold Spring Harbor, NY.

29. Strauber LA, Franchino EM, Grun J. (1989) An eight day method for screening compounds against Leishmania donovani in the golden hamster. J. Protozool. 5: 269-273.

30. D'Arpa P, Liu LF. (1989) Topoisomerase-targeting antitumor drugs. Biochim. Biophys. Acta 989: 163-177.

31. Moriera MEC, Portillo HAD, Milder RV, Balanco MF, Barcinski J. (1996) Heat shock induction of apoptosis in promastigotes of the unicellular organism Leishmania (Leishmania) amazonensis. J. Cell. Physiol. 167: 305-313.

32. Martin BS, Reutelingsperger LPM, McGahon AJ, VanSchiee RCAA, La Face DM, Greenn DR. (1995) Early redistribution of plasma membrane phosphatidylserine is a general feature of apoptosis regardless of the initiating stimulus: inhibition by overexpression of $\mathrm{Bcl} 2$ and $\mathrm{Ab} 1$. J. Exp. Med. 182: 1345-1350.

33. Chakrabarti G, Basu A, Manna PP, Mahato SB, Mandal NB, Bandyopadhyay S. (1999) Indolylquinoline derivatives are cytotoxic to Leishmania donovani promastigotes in vitro and are effective in treating murine visceral leishmaniasis. $J$. Antimicrob. Chemother. 43: 359-366.

34. Del Bino G, Bruno S, Yi PN, Darzynkiewicz Z. (1992) Apoptotic cell death triggered by camptothecin or teniposide. The cell cycle specificity and effects of ionizing radiation. Cell. Prolif. 25: 537-548. 